\title{
A five-year survey of ocular shotgun injuries in Ireland
}

\author{
DERMOT RODEN,' PHILIP CLEARY,2 AND PETER EUSTACE \\ From the 'Department of Ophthalmology, Mater Misericordiae Hospital, Dublin, and the ${ }^{2}$ Eye, Ear, and \\ Throat Hospital, Cork, Ireland
}

SUMmARY Between November 1980 and September 198520 patients in Ireland sustained accidental ocular shotgun injuries severe enough to necessitate hospital admission. Eight patients had contusion injuries and 12 perforating injuries. Contusion damage was disproportionate to the size of the pellet. Through and through perforation of the globe occurred in eight patients; the remaining four patients in this group had retained intraocular pellets. Twelve patients sustained perforating eye injuries. Those that were treated by primary closure alone lost the sight in that eye. Those treated by vitreoretinal surgery recovered vision directly related to where the pellet had its exit from the eye. It was possible to contact 15 of the patients. All 15 were shooting pheasant. It was not possible to relate the distance of the patient from the gun to the severity of the ocular injury.

Accidental shotgun injuries regularly present to ophthalmic departments in Ireland. Over 176000 shotgun licences were issued in Ireland in 1985, and game shooting is a popular sport. The injuries sustained have many distinctive features, contusion is severe, and the pellets travel towards the apex of the orbit. Perforation is common and often through and through. Vitreoretinal surgery is a prerequisite to satisfactory management of the perforating injuries. Two-thirds of the victims were shot by experienced gun handlers. Bullet and shrapnel injuries involving the eye have been extensively described by DukeElder,' and BB-gun injuries to the eye have been reported (a BB-gun is an air rifle that shoots pellets). ${ }^{23}$ Bowen and Magauran ${ }^{4}$ reported 105 cases of ocular injuries caused by airgun pellets. Conway $e t$ $a l .{ }^{5}$ mention the surgical management of two patients who suffered perforating eye injuries from shotgun pellets.

The regular presentation of ocular shotgun injuries to ophthalmologists in Ireland and the rarity of reports in the literature prompted this survey.

\section{Material and methods}

All ophthalmologists in the Republic of Ireland were circularised by letter. One of the authors (DR) telephoned each consultant, asking him if he could recall attending any patient involved in a shotgun

Correspondence to Professor P Eustace, Department of Ophthalmology. Mater Misericordiae Hospital, Dublin 7, Ireland. accident during the period November 1980 to January 1985 . Twenty patients were thus recalled. The charts were retrieved and scrutinised by the same author. Particular attention was paid to the ocular injury, its treatment, and ultimate best corrected visual acuity. Fifteen of the 20 patients were contacted about the circumstances of the accident. The age and experience of the person who shot them, the type of the gun and cartridge used, and the distance from the patient were ascertained. It was not possible to interview five patients as they could not be contacted.

\section{Results}

Twenty patients were involved in ocular shotgun accidents from November 1980 to January 1985-an average rate of four cases a year from a population of 3.8 million people. The findings of our survey are tabulated in Tables 1 and 2 . Ten of the 20 patients $(50 \%)$ presented in November, three $(15 \%)$ in December, and four $(20 \%)$ in January. All the patients were male, their ages ranging from 10 to 65 years, mean 30 years. Of the 20 patients three sustained bilateral eye injuries, accounting for 23 eyes. Thirteen of the 17 uniocular injuries $(76 \%)$ were to the right eye.

Clinically the injuries were divided into two groups:

1. CONTUSION INJURIES

Eight patients had contusion eye injuries, one patient 
Table 1 Patients with contusion injuries

\begin{tabular}{|c|c|c|c|c|c|c|c|c|c|c|}
\hline \multirow{2}{*}{$\begin{array}{l}\text { Case } \\
\text { no. }\end{array}$} & \multirow{2}{*}{$\begin{array}{l}\begin{array}{l}\text { Date of } \\
\text { presentation }\end{array} \\
2 \text { Nov } 1980\end{array}$} & \multirow{2}{*}{$\begin{array}{l}\text { Sex } \\
\mathrm{M}\end{array}$} & \multirow{2}{*}{$\begin{array}{l}\text { Age } \\
42\end{array}$} & \multirow{2}{*}{$\begin{array}{l}\text { Eye } \\
\mathrm{R}\end{array}$} & \multirow{2}{*}{$\begin{array}{l}\text { Injuries } \\
\text { Comotio retinae }\end{array}$} & \multirow{2}{*}{ 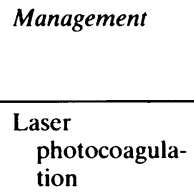 } & \multicolumn{3}{|c|}{$\begin{array}{l}\text { Ultimate Interviewed Target, } \\
\text { visual } \\
\text { acuity } \\
\text { circumstances, } \\
\text { distance }\end{array}$} & \multirow{2}{*}{$\begin{array}{c}\begin{array}{c}\text { Gun handler, age, } \\
\text { sex, relationship to } \\
\text { patient, experience }\end{array} \\
\begin{array}{c}15, \mathrm{M}, \text { acquaintance, } \\
\text { no experience }\end{array}\end{array}$} \\
\hline & & & & & & & $6 / 9$ & Yes & $\begin{array}{c}\text { Pheasant, sallies, } \\
12 \text { yards }\end{array}$ & \\
\hline 2 & 2 Nov 1982 & $\mathrm{M}$ & 33 & $\mathbf{R}$ & Comotio retinac & Conservative & $6 / 6$ & Yes & $\begin{array}{l}\text { Pheasant, ditch, } \\
60 \text { yards }\end{array}$ & $\begin{array}{l}25, \mathbf{M}, \text { brother, } \\
\text { experienced }\end{array}$ \\
\hline 3 & 20 Nov 1983 & $M$ & 30 & $\mathrm{~L}$ & Comotio retinac & Conservative & $6 / 6$ & Yes & $\begin{array}{l}\text { Pheasant, bush, } \\
60 \text { yards }\end{array}$ & $\begin{array}{l}32, \mathbf{M} \text {, relative, no } \\
\text { experience }\end{array}$ \\
\hline 4 & $20 \mathrm{Jan} 1983$ & $\mathbf{M}$ & 20 & $\mathrm{~L}$ & III palsy & Conservative & $6 / 9$ & Yes & $\begin{array}{l}\text { Pheasant, ditch, } \\
15 \text { yards }\end{array}$ & $\begin{array}{r}35, \mathrm{M} \text {, friend, } \\
\text { experienced }\end{array}$ \\
\hline \multirow[t]{2}{*}{5} & 3 Nov 1984 & $\mathbf{M}$ & 19 & $\mathbf{R}$ & $\begin{array}{l}\text { Hyphaema +comotio } \\
\text { retinae }\end{array}$ & Conservative & $6 / 6$ & Yes & $\begin{array}{l}\text { Pheasant, field, } \\
60 \text { yards }\end{array}$ & $\begin{array}{r}19, \mathbf{M}, \text { friend, } \\
\text { experienced }\end{array}$ \\
\hline & & & & $\mathrm{L}$ & Eyelid entry wound & Conservative & $6 / 6$ & & & \\
\hline 6 & $8 \mathrm{Jan} 1984$ & $\mathbf{M}$ & 29 & $\mathbf{R}$ & III, IV, V, VI palsy & Conservative & $6 / 12$ & Yes & $\begin{array}{l}\text { Pheasant, ditch, } \\
15 \text { yards }\end{array}$ & $\begin{array}{l}\text { 35, } M \text {, acquaintance, } \\
\text { experienced }\end{array}$ \\
\hline 7 & 21 Jan 1984 & $\mathbf{M}$ & 16 & $\mathbf{R}$ & Comotio retinae & Conservative & $6 / 6$ & Yes & $\begin{array}{l}\text { Pheasant, field, } \\
20 \text { yards }\end{array}$ & $\begin{array}{l}23, \mathbf{M}, \text { brother, } \\
\text { experienced }\end{array}$ \\
\hline 8 & 18 Jan 1985 & $\mathbf{M}$ & 25 & $\mathbf{R}$ & Comotio retinae & Conservative & $6 / 5$ & Yes & Pheasant, ditch & $\begin{array}{l}19, \mathbf{M}, \text { friend, no } \\
\text { experience }\end{array}$ \\
\hline
\end{tabular}

Metric conversion: 10 yards $=9 \mathrm{~m}$.

had bilateral injuries, Table 1 . In no case did a perforation occur in this group. In contusion injuries the pellet lodged in the retro-orbital tissue or in the cavernous sinuses. Contusion injuries included peri- orbital entry wounds, subconjunctival lacerations, and haemorrhages, hyphaema, comotio retinae, and transient vitreous haemorrhage (Fig. 1). In two cases (Nos. 4 and 6) the patients suffered transient cranial

Table 2 Patients with perforating injuries

\begin{tabular}{|c|c|c|c|c|c|c|c|c|c|c|}
\hline $\begin{array}{l}\text { Case } \\
\text { no. }\end{array}$ & $\begin{array}{l}\text { Date of } \\
\text { presentation }\end{array}$ & Sex & Age & Eye & Injuries & Management & $\begin{array}{l}\text { Ultima } \\
\text { visual } \\
\text { acuity }\end{array}$ & & $\begin{array}{l}\text { Target, } \\
\text { circumstances, } \\
\text { distance }\end{array}$ & $\begin{array}{l}\text { Gun handler, age, } \\
\text { sex, relationship to } \\
\text { patient, experience }\end{array}$ \\
\hline 9 & 2 Nov 1980 & $\mathbf{M}$ & 59 & $\mathrm{~L}$ & $\begin{array}{l}\text { Double perforation with } \\
\text { RD }\end{array}$ & $1^{\circ}$ Closure & HM & Yes & $\begin{array}{l}\text { Pheasant, field, } \\
100 \text { yards }\end{array}$ & $\begin{array}{l}55, M, \text { friend } \\
\text { experienced }\end{array}$ \\
\hline 10 & 4 Dec 1980 & $\mathbf{M}$ & 45 & $\mathbf{R}$ & $\begin{array}{l}\text { Single perforation, } \\
\text { phthisical }\end{array}$ & $1^{\circ} \mathrm{Closure}$ & NPL & $\begin{array}{l}\text { No } \\
\text { response }\end{array}$ & & \\
\hline 11 & 4 Jan 1981 & $\mathbf{M}$ & 29 & $\mathbf{R}$ & $\begin{array}{l}\text { Double perforation, } \\
\text { phthisical }\end{array}$ & $1^{\circ}$ Closure & NPL & Yes & $\begin{array}{l}\text { Rabbit, ditch, } \\
10 \text { yards }\end{array}$ & $\begin{array}{l}\text { 33, } \mathrm{M} \text {, brother, } \\
\text { experienced }\end{array}$ \\
\hline 12 & 12 Nov 1982 & $\mathbf{M}$ & 65 & $\mathbf{L}$ & $\begin{array}{l}\text { Double perforation, vit. } \\
\text { haem. RD }\end{array}$ & $1^{\circ}$ Closure & HM & Yes & Pheasant, 20 yards & $\begin{array}{l}\text { 33, } \mathrm{M} \text {, friend, no } \\
\text { experience }\end{array}$ \\
\hline 13 & 13 Nov 1982 & $\mathbf{M}$ & 15 & $\mathbf{R}$ & $\begin{array}{l}\text { Double perforation, } \\
\text { phthisical }\end{array}$ & $1^{\circ} \mathrm{Closure}$ & NPL & Yes & $\begin{array}{l}\text { Pheasant, field, } \\
30 \text { yards }\end{array}$ & $45, \mathrm{M}$, no experience \\
\hline 14 & 6 May 1983 & $\mathbf{M}$ & $?$ & $\mathbf{R}$ & $\begin{array}{l}\text { Double perforation, } \\
\text { phthisical }\end{array}$ & $1^{\circ}$ Closure & NPL & $\begin{array}{l}\text { No } \\
\text { response }\end{array}$ & & \\
\hline \multirow[t]{2}{*}{15} & 22 Aug 1983 & $\mathbf{M}$ & 29 & $\mathbf{R}$ & Double, aphakia & $\begin{array}{l}1^{\circ} \text { Closure } \\
\quad+\text { vitrectomy }\end{array}$ & $6 / 9$ & $\begin{array}{l}\text { No } \\
\text { response }\end{array}$ & Family feud & \\
\hline & & & & $\mathrm{L}$ & Single, aphakia & $\begin{array}{l}1^{\circ} \text { Closure } \\
\quad+\text { vitrectomy }\end{array}$ & $\mathrm{CF}$ & & & \\
\hline 16 & 4 Nov 1983 & $\mathbf{M}$ & 14 & $\mathbf{R}$ & Single, vit. haem. & $\begin{array}{l}1^{\circ} \text { Closure } \\
\quad+\text { vitrectomy }\end{array}$ & $6 / 12$ & $\begin{array}{l}\text { No } \\
\text { response }\end{array}$ & & \\
\hline 17 & 27 Dec 1983 & $\mathbf{M}$ & 40 & $\mathbf{R}$ & $\begin{array}{l}\text { Double perforation, } \\
\text { phthisical }\end{array}$ & $\begin{array}{l}1^{\circ} \text { Closure } \\
+ \text { vitrectomy }\end{array}$ & NPL & Yes & $\begin{array}{l}\text { Woodcock, ditch, } \\
60 \text { yards }\end{array}$ & $\begin{array}{l}\text { 45, } \mathrm{M}, \text { uncle, } \\
\text { experienced }\end{array}$ \\
\hline 18 & 5 Nov 1983 & $\mathbf{M}$ & 25 & $\mathbf{R}$ & $\begin{array}{l}\text { Double, aphakia, vit. } \\
\text { hacm. }\end{array}$ & $\begin{array}{l}1^{\circ} \text { Closure } \\
\quad+\text { vitrectomy }\end{array}$ & $6 / 60$ & & & \\
\hline 19 & 17 Nov 1984 & $\mathbf{M}$ & 10 & $\mathbf{R}$ & Single, phthisical & $1^{\circ}$ Closure & NPL & Yes & $\begin{array}{l}\text { Pheasant, ditch, } \\
30 \text { yards }\end{array}$ & $21, \mathrm{M}$, brother \\
\hline \multirow[t]{2}{*}{20} & 4 Dec 1984 & $\mathbf{M}$ & 24 & $\mathbf{R}$ & $\begin{array}{l}\text { Double, vit. haem., } \\
\text { aphakia }\end{array}$ & Vitrectomy & $2 / 60$ & Yes & $\begin{array}{l}\text { Pheasant, ditch, } \\
15 \text { yards }\end{array}$ & $\begin{array}{l}\text { 34, M, friend, } \\
\text { experienced }\end{array}$ \\
\hline & & & & $\mathrm{L}$ & $\begin{array}{l}\text { Double, vit. hacm., } \\
\text { aphakia }\end{array}$ & Vitrectomy & $6 / 9$ & & & \\
\hline
\end{tabular}

$\mathrm{CF}=$ counting fingers. $\mathrm{HM}=$ hand movements. $\mathrm{NPL}=$ no perception of light. 


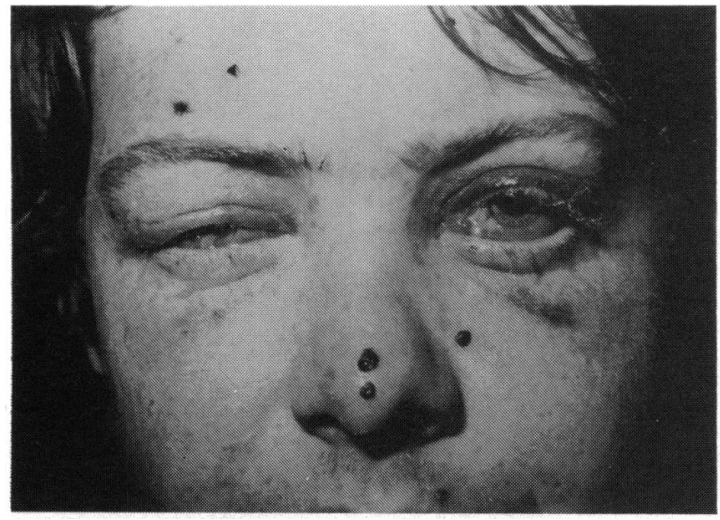

Fig. 1 Typical presentation of a patient with shotgun injuries.

nerve palsies, which recovered within three months. All of the contusion injuries were managed conservatively. There was no attempt to remove the pellets unless they were palpably superficial.

In all nine eyes the visual acuity recovered to $6 / 12$ or better without surgical intervention. Two years after the initial injury a retinal tear developed in case 1 . This was satisfactorily treated by laser photocoagulation.

\section{PERFORATING INJURIES}

Twelve patients had perforating eye injuries and two of these were bilateral, so that there were 14 eyes in this group (Table 2). In four eyes the pellet was retained within the globe; in the other 10 a double perforation occurred, and the pellet had its exit posteriorly from the globe into the orbit. The entry wound was either corneal, limbal, or scleral anterior to the equator (Fig. 2). Hyphaema, cataract, and vitreous haemorrhage obscured the exit site until vitreoretinal repair cleared the visual media. Seven of the 14 eyes were managed by primary closure of

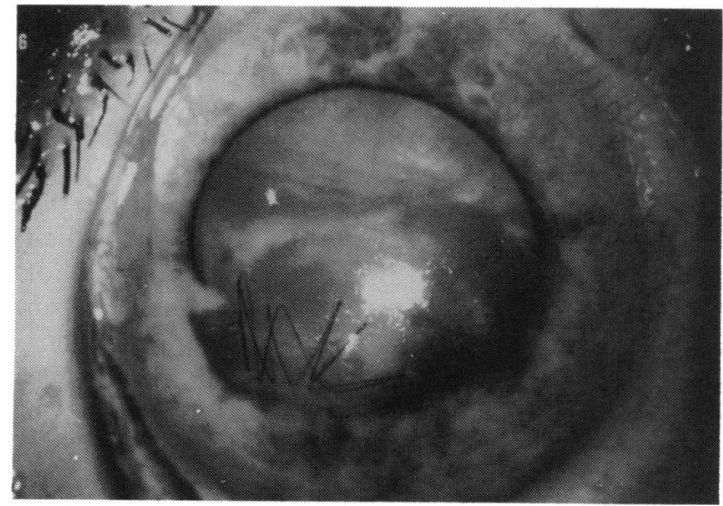

Fig. 2 A corneal entry wound. the entry site alone. Five of these never recovered any sight and progressed to phthisis bulbi; two had hand movement vision.

The remaining seven cases were treated by vitreoretinal surgery within a week of primary closure of the entry wound. Three cases recovered a visual acuity of $6 / 12$ or better, one case $6 / 60$, one $2 / 60$, one counting fingers, and one no perception of light, with phthisis bulbi.

Fifteen of the 20 patients were interviewed. All were shot by accident while shooting pheasant. Nine of the 15 patients $(60 \%)$ stated that there was a ditch or hedge between themselves and the person who accidentally shot them. The range of fire varied from 10 to 100 yards $(90 \mathrm{~m})$ with an average range of 38 yards $(35 \mathrm{~m})$.

Both hunters and patients were male. Four of the 15 people were shot by their brothers. They were aged between 15 and 55 and averaged 33 years. In the patients' own estimation 10 of 15 people $(66 \%)$ had good experience with shotguns, while five of 15 $(33 \%)$ had no or very little experience. The gun used was usually a 12 bore double barrel shotgun with a No. 5 or 6 cartridge.

\section{Discussion}

Accidental ocular shotgun injuries are a regular occurrence during the shooting season. This study revealed on average four new cases each year. Accidents occurred mainly in November, $50 \%$ in our series. November is the first month of the pheasant shooting season. Awareness by the hunters and particular caution at the start of the season may reduce this incidence.

Contusion injuries are treated conservatively, but there is risk of a late retinal detachment. The visual prognosis in these cases was good-6/12 or better. In two cases (Nos. 4 and 6) there were transient cranial nerve palsies. The pellet in both cases entered the orbit medial to the globe, and a CT scan showed the pellet in the cavernous sinus. The pellets were left in situ and both patients made full neurological recovery within three months of the injury. Contusion injury is disproportionately much greater than the size of the pellet.

Pellet toxicity has been considered by Bowen and Magauran. ${ }^{4}$ They measured blood and urine lead levels in four patients with retained intraorbital pellets. These values remained within normal values up to six years after the injury. All postseptal pellets have been left in situ in our series of patients without ill effect.

Perforation of the globe was the most serious result of a shotgun injury. These perforations are sometimes single, often double, and were characterised by 
Fig. 3 Ultrasonographic demonstration of an intravitreal haemorrhage (arrow) in a patient with a double perforating injury.

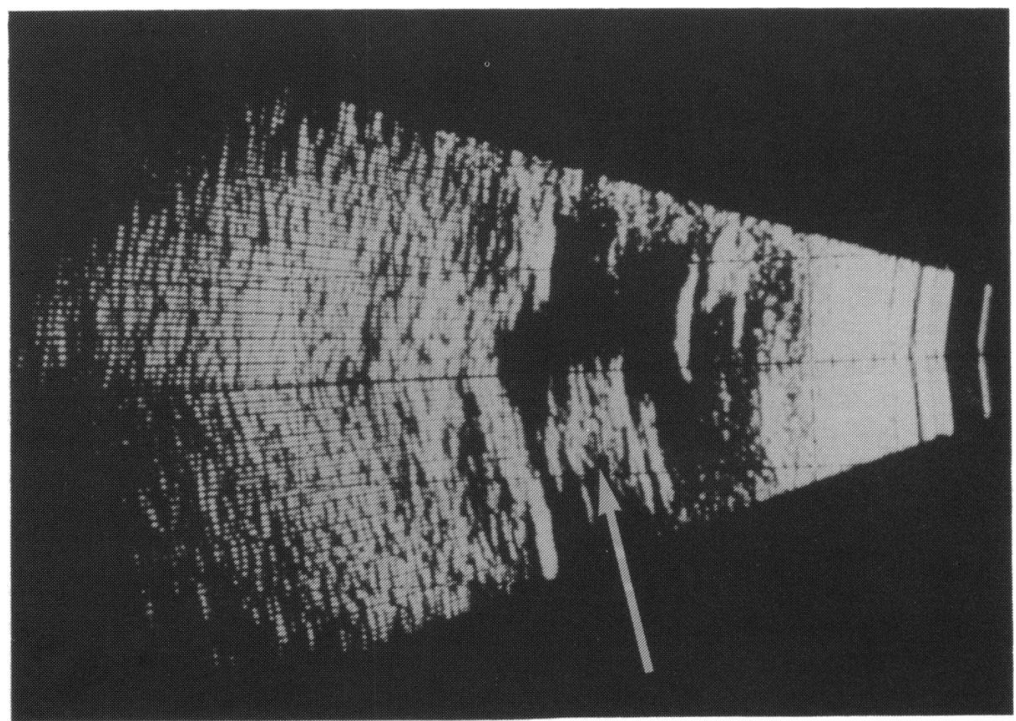

intraocular haemorrhage (Fig. 3), vitreous incarceration, and a possible retinal detachment. It has been shown experimentally ${ }^{67}$ and it is recognised clinically ${ }^{8}$ that perforating injuries (with these complications) have poor prognosis when treated by conventional techniques. In this study seven eyes were treated by primary closure alone and none recovered useful vision, with the development of phthisis in five. In contrast, the seven eyes treated by vitrectomy within one week of primary closure had a much more

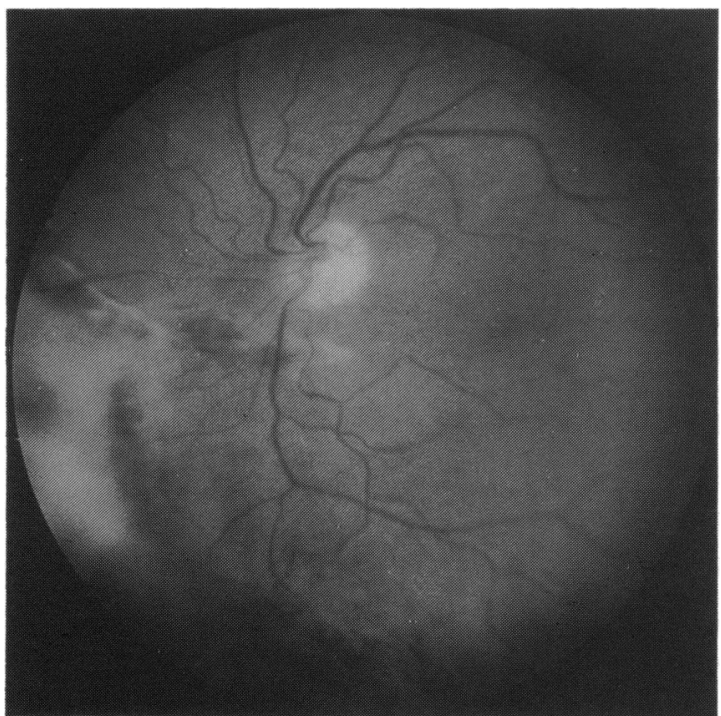

Fig. 4 Case 20. The left fundus showing an equatorial exit. The visual acuity is $6 / 9$. favourable visual outcome. Three of the seven regained a visual acuity of $6 / 12$ or better, and in the other four the eye was salvaged but the visual potential had been destroyed by the pellet leaving the eye at or near the macula.

Perforating injuries involving the posterior segment result in vitreous gel incarceration and vitreous haemorrhage. This progresses to retinal traction and tractional retinal detachments. In those cases which underwent vitrectomy we consider the scaffolding on which the contractile fibroblasts proliferate was removed, aborting the retinal traction and detachment and salvaging the visual potential of the eye.

It has been suggested previously that visual outcome may be related to the entry site of the pellet. ${ }^{y}$ In our series the visual outcome was related to where the pellet had its exit from the globe. In the two bilateral perforation injuries (cases 15 and 16) the visual acuity was $6 / 9$ where the pellet had its exit at the equator (Fig. 4). In contrast, the visual acuity was counting fingers and $2 / 60$ when the pellet left the eye at or near the macula (Fig. 5).

Fifteen of the 20 patients were interviewed, nine of them described the accident occurring through a ditch or hedge. We found no correlation between the severity of the injury and the distance from which they were shot. Indeed one case (No. 9) was shot from 100 yards $(90 \mathrm{~m})$. He had a double perforation and the eye was lost. He received no other injuries. It is noteworthy that 10 of the 15 were shot by people who, in the patients' estimation, were experienced.

In conclusion, the results in this study suggests that, after a shotgun injury, contusion eye injuries are best treated conservatively. But eyes with perfor- 


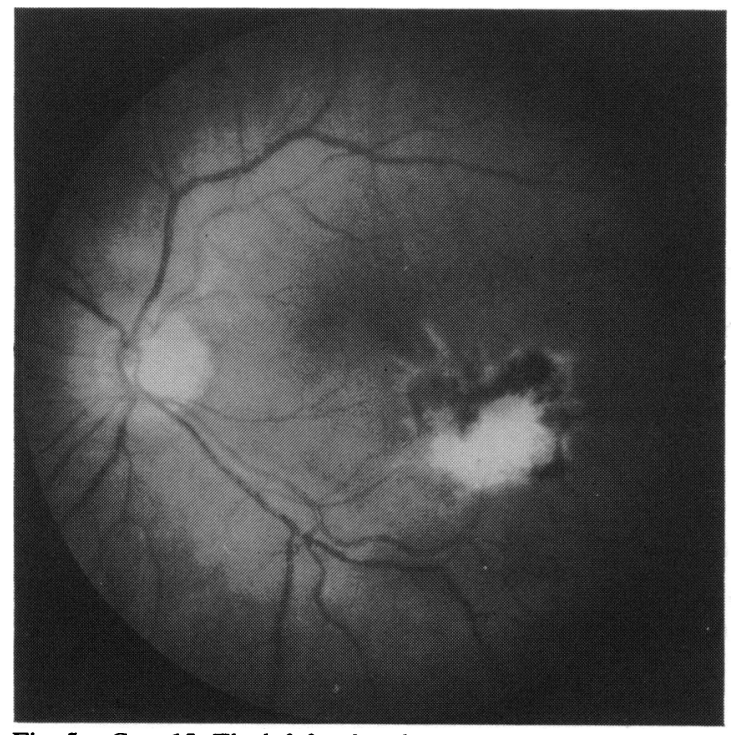

Fig. 5 Case 15. The left fundus showing a paramacula exit. The visual acuity is $C F$.

ating injuries should, after primary closure, be considered for early vitrectomy in the presence of significant intraocular haemorrhage and/or retinal detachment. In the assessment of these cases ophthalmic ultrasound is of particular value.

By publicising the risk of these injuries to gun clubs and other interested parties the incidence of these avoidable, serious ocular injuries may be reduced. We are unable to make any additional recommendations to the safety standards already obtaining.

The authors acknowledge with gratitude the co-operation of ophthalmologists in Ireland in providing us with the patients for this survey.

This work was supported by a grant in aid from Mater Hospital College for Postgraduate Education and Research, Dublin 7.

\section{References}

1 Duke-Elder S. System of ophthalmology. London: Mosby, 1972: $15(1): 676-92$.

2 Brown GC, Tasman WS, Benson WE. BB-gun injuries to the eye. Ophthalmic Surg 1985; 16: 505-8.

3 Kreshon MJ. Eye injuries due to BB-Guns. Ophthalmology (Rochester) 1964; 58: 858-61.

4 Bowen DI, Magauran DM. Ocular injuries caused by airgun pellets. Br Med J 1973; i: 333-7.

5 Conway BP, Michels RG. Vitrectomy techniques in the management of selected penetrating ocular injurics. Ophthalmology $1978 ; 85: 560-3$.

6 Clcary PE, Ryan SJ. Method of production and natural history of experimental posterior penetrating eyc injury in the rhesus monkey. Am J Ophthalmol 1979; 88: 212-21.

7 Cleary PE, Ryan SJ. Histology of wound, vitreous and retina in experimental posterior penetrating eyc injury in the rhesus monkey. Am J Ophthalmol 1979; 88: 221-31.

8 Michels RG. Vitreous surgery. St Louis: Mosby, 1981: 273

9 Edmund J. The prognosis of perforating cyc injurics. Acta Ophthalmol (Kbh) 1968; 46: 1165-74.

Accepted for publication 29 July 1986. 